\title{
KAJIAN LITERATUR PERLINDUNGAN HUKUM HAK KEKAYAAN INTELEKTUAL DALAM INDUSTRI KREATIF
}

\author{
Wahyu Suwarni \\ Program Studi Fotografi, Jurusan Penerbitan, Politeknik Negeri Media Kreatif \\ Korespondensi: Jalan Srengseng Sawah, Jagakarsa, Jakarta Selatan \\ Surel: wahyusuwarni@polimedia.ac.id
}

\section{INFO ARTIKEL}

\section{Sejarah Artikel:}

Diterima: 06/01/2021

Direvisi: 20/01/2021

Dipublikasikan: 30/01/2021

e-ISSN: 2721-0995

p-ISSN: 2721-9046

\section{Kata Kunci:}

Perlindungan Hukum

Hak Kekayaan Intelektua, Industri Kreatif

Keywords:

Legal Protection

Intellectual Property Rights

Creative Industries
ABSTRAK Kajian Literatur Perlindungan Hukum Hak Kekayaan Intelektual dalam Industri Kreatif. Perlindungan hukum dapat dilakukan terhadap produk industri kreatif, di antaranya hak cipta buku, hak merchandising, fotografi, pemrograman komputer, karya cipta musik dan lagu, serta terhadap rahasia dagang, merek dan paten. Tujuan kajian ini untuk mengetahui pentingnya perlindungan hukum dalam industri kreatif melalui pendekatan yuridis normatif dengan sifat penelitian deskriptif berupa pendeskripsian atas suatu peristiwa hukum. Hasil kajian literatur menunjukkan bahwa adanya perlindungan hukum yang dilakukan secara preventif (upaya pencegahan) berupa pendaftaran/pencatatan dan represif (upaya setelah terjadi pelanggaran terhadap karya kekayaan intelektual) berupa sanksi. Perlindungan hukum secara khusus sudah diberikan bagi produk industri kreatif yang telah didaftarkan melalui Direktorat Jenderal Kekayaan Intelektual yang dibuktikan dengan sertifikat Hak Kekayaan Intelektual.

\section{ABSTRACT Literature Study of Legal Protection of} Intellectual Property Rights in Creative Industries. Legal protection can be carried out for products of creative industries, including copyrights of books, merchandising, photography, computer programming, music and song, trade secrets, brands and patents. The purpose of this study is to determine the importance of legal protections in the creative industry, through a normative juridical approach with describing the characteristics of legal events. The results of the literature review show that the existence of preventive legal protection (i.e. preventive measures) in the form of registration and repressive (after an intellectual property work violation) takes the form of sanctions. Specific legal protections have been given to the creative industrial products that have been registered through the Directorate General of Intellectual Property with a certificate of Intellectual Property Rights as an evidence to get the protection. 


\section{PENDAHULUAN}

Indonesia merupakan negara hukum, bukan negara yang berdasarkan kekuasaan belaka. Dengan demikian, seluruh aspek penyelenggaraan negara harus tunduk dan patuh terhadap kaidah-kaidah hukum. Hukum ditegakkan sebagai pondasi utama dalam kegiatan kehidupan berbangsa dan bernegara, baik skala nasional maupun internasional. Sebagai bagian dari masyarakat internasional, Indonesia telah melakukan Persetujuan Pembentukan Organisasi Perdagangan Dunia dengan dikeluarkannya Undang-Undang Nomor 7 Tahun 1994. Akibat adanya Undang-Undang Nomor 7 Tahun 1994, Indonesia berkewajiban menyesuaikan setiap peraturan perundang-undangan dengan ratifikasi tersebut, seperti hukum hak kekayaan intelektual. Dimasukkannya perlindungan kekayaan intelektual dalam perjanjian internasional memberikan kepastian hukum serta prosedur penegakan hukum terhadap keseimbangan hak dan kewajiban demi terciptanya kesejahteraan sosial dan ekonomi (Tjokorda Udiana Nindhia Pemayun et. al., 2017, h. 41).

Hak Kekayaan Intelektual (HKI) dilindungi untuk menunjang kehidupan manusia, khususnya yang memiliki nilai ekonomi karena kemampuan intelektualitas manusia atas penguasaan hasil karya tersebut dapat menguntungkannya. Hal itu seperti yang diungkapkan Sulasi Rongiyati (2018, h. 42), yakni HKI timbul dari karya, karsa, cipta yang didapatkan dari kreativitas dan olah pikir manusia yang diwujudkan dalam bentuk nyata serta bermanfaat bagi bangsa. Indonesia sudah memiliki payung hukum perlindungan intelektual, di antaranya Undang-Undang Nomor 19 Tahun 2002 yang diperbarui dengan Undang-Undang Nomor 28 Tahun 2014 mengenai Hak Cipta. Selanjutnya, Undang-Undang Nomor 30 Tahun 2000 tentang Rahasia Dagang. Lalu Undang-Undang Nomor 14 Tahun 2001 diperbarui dengan Undang-Undang Nomor 13 Tahun 2016 tentang Paten. Sebelumnya, regulasi mengenai Hak Merek tertuang dalam Undang-Undang Nomor 15 Tahun 2001 tentang Merek. Namun sejak 2016, Pemerintah mengeluarkan Undang-Undang Nomor 20 Tahun 2016 tentang Merek dan Indikasi Geografis.

Dalam Undang-Undang $\mathrm{HKI}$ tersebut sangat memberikan perlindungan bagi pencipta, di antaranya terhadap pemilik hak cipta berlaku selama 70 tahun, sedangkan bentuk perlindungan inventor di bidang paten selama 20 tahun. Perlindungan terhadap pencipta merek selama 10 tahun sejak tanggal diterimanya pendaftaran terhadap merk dan jangka waktu perlindungan itu dapat diperpanjang. Meskipun bentuk perlindungan hukum terhadap HKI sudah diatur dalam perundang-undangan di Indonesia, salah satu masalah yang masih ada, yaitu adanya globalisasi sehingga menimbulkan minimnya proteksi software original, seperti yang dikemukaan Tjokorda Udiana Nindhia Pemayun et. al. (2017, 47) bahwa dengan semakin pesatnya perkembangan teknologi internet, memudahkan tindakan pengopian secara ilegal terhadap produk kekayaan intelektual tersebut.

Mengenai maraknya pembajakan software komputer, walaupun Indonesia telah memiliki Undang-Undang Nomor 11 Tahun 2008 tentang Informasi dan Transaksi Elektronik, Peraturan Pemerintah Republik Indonesia Nomor 29 Tahun 2004 tentang Sarana Produksi Berteknologi Tinggi untuk Cakram Optik, Undang-Undang Nomor 28 Tahun 2014 tentang 
Hak Cipta, kenyataannya menurut Arma (2016, h. 73) masih terdapat hambatan dalam menanggulangi pembajakan software salah satunya, yaitu minimnya daya beli masyarakat dalam membeli software original. Hal senada pun dikemukakan Oksidelfa Yanto (2015, h. 105) yang menjelaskan bahwa terdapat faktor yang menimbulkan terus meluasnya tindak pembajakan terhadap hak cipta khususnya karya musik. Selain faktor harga DVD/VCD original yang mahal, juga faktor ekonomi yang disebabkan oleh semakin bertambahnya angka pengangguran sehingga memicu masyarakat untuk menjual produk bajakan, dalam hal ini, karya musik dalam bentuk DVD/VCD. Faktor ekonomi itulah yang menjadi dalih seseorang untuk mengunduh musik secara ilegal. Berdasarkan latar belakang tersebut, permasalahan yang difokuskan adalah bentuk perlindungan HKI terhadap produk industri kreatif itu seperti apa.

\section{TINJAUAN PUSTAKA}

Beberapa kajian literatur yang menjadi landasan diperlukan perlindungan hukum kekayaan intelektual pada industri kreatif, di antaranya penelitian Rois dan Roisah (2018, h. 417) mengenai perlindungan hukum terhadap karya kreatif kerajinan kuningan tumang, yaitu faktor politik (belum terciptanya kebijakan dan sosialisasi dari pemerintah tentang Perlindungan Hak Kekayaan Intelektual); faktor budaya (mayoritas pengrajin kuningan tumang beranggapan mengikuti ciptaan orang lain adalah hal yang normal dan tidak perlu disalahkan serta ketidaktahuan pengrajin betapa penting fungsi merek yang melekat pada karya kerajinannya); faktor sosial (eratnya hubungan persaudaraan di desa TumangKabupaten Boyolali—seperti halnya pada masyarakat komunal—mengakibatkan setiap muncul ide terhadap karya kuningan, ide tersebut menjadi milik bersama); dan faktor ekonomi (pengrajin hanya memprioritaskan besarnya permintaan pasar sehingga mengabaikan perlindungan $\mathrm{HKI}$ ). Perlindungan hukum terhadap industri kreatif semakin penting saat produk kreatif tersebut menyumbangkan pendapatan daerah yang tidak sedikit, seperti yang diungkapkan Asri (2020, h. 150) bahwa urgensi perlindungan hak ekonomi pencipta perlu dilakukan mengingat pasar industri kreatif terus mengalami peningkatan yang signifikan dan memberikan pemasukan terhadap pendapatan bruto di Daerah Istimewa Yogyakarta sekitar 59\% atas produk kreatif UKM.

\section{METODE}

Metode penelitian ini menggunakan pendekatan yuridis normatif dengan sifat penelitian deskriptif. Metode penelitian yuridis normatif merupakan metode yang didasarkan pada meneliti bahan pustaka, dalam hal ini peraturan perundang-undangan terkait suatu perkara hukum (Sulasi Rongiyati, 2018, 44). Pendekatan penelitian ini menggunakan Undang-Undang Hak Kekayaan Intelektual, yaitu Undang-Undang Nomor 28 Tahun 2014 tentang Hak Cipta, Undang-Undang Nomor 30 Tahun 2000 tentang Rahasia Dagang, Undang-Undang Nomor 13 Tahun 2016 tentang Paten, Undang-Undang Nomor 20 Tahun 2016 tentang Merek dan Indikasi Geografis. Kajian perlindungan hukum dilakukan 
terhadap produk industri kreatif, di antaranya hak cipta buku, hak merchandising, fotografi, pemrograman komputer, serta karya cipta musik dan lagu, serta terhadap rahasia dagang, merek dan paten. Jenis penelitian ini merupakan kajian literatur dengan menggunakan 17 (tujuh belas) jurnal nasional terkait dengan Hak Kekayaan Intelektual.

\section{HASIL DAN PEMBAHASAN}

Perlindungan cenderung terkait dengan tindakan seseorang atau beberapa orang baik berupa badan hukum atau organisasi pemerintahan yang memberikan penjaminan atas rasa aman, tentram, dan sejahtera kepada pihak yang dilindungi dari kemungkinan munculnya ancaman yang dapat membahayakan jiwa serta hartanya (Denny Kusmawan, 2014, h. 138). Sementara makna perlindungan hukum, menurut Sulasi Rongiyati (2018, h. 47-49) dengan mengutip pendapat Satjipto Rahardjo mengemukakan bahwa hukum bertujuan untuk mengayomi masyarakat melalui kepastian hukum. Hal tersebut sesuai dengan dasar negara Indonesia Pancasila yang mengakui dan melindungi harkat martabat manusia, salah satu contohnya melakukan perlindungan terhadap karya intelektual anak bangsa dari tindakan pihak lain yang dapat merugikan pencipta.

Pelindungan preventif dalam Undang-Undang Hak Cipta, Undang-Undang Merek dan Indikasi Geografis, Undang-Undang Rahasia Dagang serta Undang-Undang Paten merupakan upaya pencegahan agar tidak terjadi pelanggaran hukum terhadap HKI. Dalam hal ini pelindungan preventif yang diberikan pada peraturan perundang-undangan bidang kekayaan intelektual sangat bergantung pada pemilik karya intelektual tersebut.

Dalam hal hak kekayaan intelektual, azas yang dianut Indonesia adalah first to file, artinya perlindungan hukum jatuh kepada pihak yang kali pertama mendaftarkan karya intelektualnya sesuai persyaratan perundang-undangan. Dengan demikian, untuk mencegah kemungkinan timbulnya aksi plagiat terhadap hasil karya pencipta, UndangUndang Hak Kekayaan Intelektual memberikan solusi kepada pencipta untuk mendaftarkan karya intelektualnya (Sulasi, 2018, h.51).

Selain itu, urgensi pencatatan Hak Cipta (UU Hak Cipta Nomor 28 Tahun 2014) kata pendaftaran berubah menjadi pencatatan. Sujana dan Etty (2015, h.45-47) mengemukaan pentingnya menggunakan perjanjian tertulis terhadap karya intelektual. Dengan adanya kesepakatan tertulis tersebut menjadi alat bukti yang sah di persidangan, contoh pada karya foto untuk kepentingan promosi komersial. Melalui perjanjian tertulis kemungkinan terjadinya penyangkalan atas kewajiban yang melekat oleh para pihak dapat diminimalkan.

Terkait dengan karya fotografi, Eva Puspitarani, et.al., (2014, h.3-4) mengingatkan agar fotografer meminta izin terlebih dahulu kepada model (pihak yang dipotret) ataupun ahli warisnya jika akan menggunakan foto/potret untuk kepentingan komersial. Apabila fotografer mengabaikan hal tersebut, ia akan mendapatkan sanksi pidana denda maksimal Rp500.000.000,00 (Pasal 115 Undang-Undang Nomor 28 tahun 2014). Tidak hanya hukuman materiel, hukuman moral juga akan terus melekat apabila pihak yang melanggar hak cipta juga berprofesi sebagai fotografer, seperti yang diungkapkan Nurul Liza Anjani, 
Etty Susilowati (TT, h. 4-5) sanksi nonmateriel yang didapatkannya adalah menurunnya kredibilitas fotografer tersebut yang berakibat karier profesi fotografi di masa yang akan datang menjadi terhambat.

Ada tiga kategori perlindungan Hak Cipta yang terdapat di Undang-Undang Nomor 28 Tahun 2014, yaitu:

1. 70 (tujuh puluh) tahun untuk ciptaan berupa buku, pamflet, dan semua karya tulis lainnya, karya cipta lagu dan musik dengan atau tanpa teks serta 50 (lima puluh) tahun perlindungan hak cipta untuk Badan Hukum (Pasal 58 ayat 1, 2, dan 3);

2. 50 (lima puluh) tahun sejak kali pertama dilakukan pengumuman terhadap ciptaan berupa karya fotografi, potret, program komputer (Pasal 59 ayat 1);

3. 25 (dua puluh lima) tahun bentuk perlindungan terhadap karya seni terapan (Pasal 27 ayat 2).

Dalam hal hak pencipta dan/atau pemegang hak cipta dibagi menjadi hak ekonomi dan hak moral. Hak ekonomi adalah mengizinkan atau melarang orang lain untuk mengumumkan dan/atau memperbanyak ciptaannya secara komersial. Yang termasuk hak ekonomi (Pasal 9 Undang-Undang Hak Cipta) adalah penerbitan ciptaan; penggandaan ciptaan dalam segala bentuknya; penerjemahan ciptaan; pengadaptasian, pengaransemenan, atau pentransformasian ciptaan; pendistribusian ciptaan atau salinannya; pertunjukan ciptaan; pengumuman ciptaan; komunikasi ciptaan; dan penyewaan ciptaan. Sementara itu, hak moral adalah hak yang melekat pada pencipta, dalam hal ini nama pencipta selalu dicantumkan dalam ciptaan. Hak moral ini tidak bisa dialihkan sebagai hak ekonomi.

Hak ekonomi dan hak moral yang terdapat dalam Undang-Undang Hak Cipta tidak berseberangan dengan kaidah Islam, seperti yang dipaparkan Febri Dwi Setyawan (2013, h. 402) pada fatwa MUI Hak Kekayaan Intelektual dikategorikan sebagai Haq al maliyah (hak kekayaan) atas dasar itulah berhak memperoleh perlindungan sebagai mal (kekayaan) asalkan Hak Kekayaan Intelektual tidak bertentangan dengan hukum Islam. Lebih lanjut, MUI melarang dan menegaskan kepada para pihak mengopi ataupun melakukan pembajakan karya cipta, dan tindakan sejenisnya tanpa seizin pencipta. Selain itu, tindakan tersebut dapat dikategorikan sebagai perbuatan zalim.

Selain memiliki hak ekonomi dan hak moral, hak cipta tidak bisa dialihkan kepada pihak lain selama pencipta masih hidup, kecuali wasiat pencipta ataupun dengan perikatan lisensi sesuai peraturan perundang-undangan (Pemayun, 2017, h.46). Terkait dengan pengalihan hak berupa lisensi Rezky Lendi Marimis (2014, h. 124) mengungkapkan argumennya sesuai dengan perundang-undangan di bidang hak cipta, besaran royalti yang diterima pemegang hak cipta dari pihak penerima lisensi diatur berdasarkan kesepakatan kedua belah pihak yang berpedoman pada organisasi profesi.

Adapun upaya preventif terhadap pelanggaran pada jaringan internet menurut Rantung R.A (2014, h.110), yaitu menutup situs-situs yang terbukti melanggar hak cipta, melakukan pelaporan terkait adanya situs penyebar tersebut kepada pihak berwajib, langkah terakhir baik pemerintah maupun pihak swasta menyelenggarakan sosialisasi di masyarakat. 
Membicarakan tentang hak merchandising dalam memajukan sektor industri kreatif, bila berpijak pada prinsip ekonomi landasannya adalah cost dan benefit. Namun dari sisi hukum menitikberatkan pada pembangunan hukum, artinya perlindungan hukum terhadap hak merchandising harus berpihak kepada kemajemukan tatanan hukum yang berlaku, meningkatkan kepastian hukum dan menjamin HAM, menimbulkan kesadaran hukum bagi masyarakat, memberikan layanan secara adil, benar, tertib dan menyejahterakan seluruh elemen rakyat dalam mendukung pembangunan bangsa dan penyelenggaraan negara yang memiliki daya saing global sebagai upaya memfilter gencarnya pengaruh globalisasi (Muhamad Djumhana, 2015, h.214).

Upaya preventif menurut Undang-Undang Hak Cipta, yaitu memberikan perlindungan terhadap program komputer; memberikan perlindungan hak informasi manajemen elektronik; memberikan perlindungan hak cipta melalui sarana kontrol teknologi juga melalui sarana kontrol berteknologi tinggi cakram optik (optical disc). Sementara itu, upaya pencegahan melalui Perjanjian TRIPs dalam Ketentuan Umum Penegakan Hukum Kekayaan Intelektual dengan kebijakan hukum administratif dan perdata; melalui aktivitas provisional measures; perbuatan delik pidana; keberadaan tapal batas di wilayah Indonesia dengan negara tetangga ataupun di zona laut internasional; perubahan yang kondusif terhadap kepatuhan Indonesia terkait perjanjian TRIPs dalam menegakkan hukum Undang-Undang Hak Cipta; serta penyelesaian sengketa di luar pengadilan misalnya melalui arbitrase. (Reyfel A. Rantung, 2014, h.110).

Tidak hanya pada hak cipta, kontrak/perjanjian tertulis juga merupakan bentuk perlindungan hukum secara preventif pada Rahasia Dagang khususnya dalam kerja sama franchise. Amirah, Ahmadi Miru, Nurfaidah Said (2015, h.7-8) menguatkan argumen mengenai bentuk perlindungan secara preventif melalui kontrak. Kontrak atau perjanjian memiliki kedudukan yang vital dalam hukum. Perjanjian yang mencantumkan hak dan kewajiban kedua belah pihak harus dijalankan dengan kejujuran agar transaksi bisnis terlindungi.

Pembahasan selanjutnya mengenai Merek, berdasarkan ketentuan Undang-Undang Nomor 15 Tahun 2001 tentang Merek, Indonesia memiliki aturan yang jelas terhadap pelanggaran Merek, yaitu:

1. adanya kesamaan merek secara keseluruhan dengan pihak lain yang mana merek tersebut sudah didaftarkan terlebih dahulu di Dirjen HKI (Pasal 90);

2. adanya kesamaan merek pada pokoknya (Pasal 91);

3. melakukan transaksi penjualan atas barang/jasa yang merupakan hasil kejahatan (Pasal 94 ayat 1$)$

Hak eksklusif merupakan hak yang dimiliki pemegang merek, berarti hanya pemilik mereklah yang berhak menggunakan hak atas merek yang telah didaftarkannya tersebut dan tidak mengizinkan pihak lain untuk memakai dan memiliki merek itu. Namun, hak tersebut dapat dibatalkan dengan adanya izin dari pemilik merek, seperti yang diungkapkan oleh Ida Ayu Windhari Kusuma Pratiwi (2014, h.430), yaitu izin dari pemilik merek yang dituangkan 
dalam perjanjian lisensi (licencing agreement). Dengan catatan, perjanjian lisensi tersebut berlaku untuk merek yang telah didaftarkan. Berdasarkan Pasal 28 Undang-Undang Nomor 15 Tahun 2001 tentang Merek, merek terkenal mendapat perlindungan hukum selama 10 (sepuluh) tahun sejak tanggal penerimaan dan jangka waktu perlindungan itu dapat diperpanjang. Dengan demikian, perlindungan merek secara preventif dapat dilakukan apabila pemilik merek tersebut mendaftarkan mereknya di Ditjen HAKI Kementerian Hukum dan HAM.

Tindakan represif merupakan upaya pelindungan hukum terakhir berupa sanksi apabila sudah terjadi peristiwa pelanggaran berdasarkan tinjauan hukum pidana dan perdata. Salah satu bentuk tindakan represif dapat dilakukan dengan menegur secara tertulis pada kontrak atau perjanjian kerjasama yang telah disepakati atau ditandatangani oleh para pihak. Apabila terjadi pelanggaran hak cipta, upaya represif menurut Sujana dan Etty (2015, h. 48-49) dapat ditempuh dengan beberapa cara, antara lain:

1. Melalui Alternatif Penyelesaian Sengketa

a. Mediasi merupakan jalur penyelesaian sengketa melalui pihak yang netral dan independen, baik berupa swasta, perorangan, maupun lembaga PMN (Pusat Mediasi Nasional), mediator dipilih oleh pihak-pihak yang berperkara;

b. Negosiasi merupakan upaya penyelesaian konflik selain melalui pengadilan yang bertujuan tercapainya kesepakatan kedua belah pihak untuk bekerja sama secara harmonis dan kreatif;

c. Konsiliasi bertujuan menemukan solusi terhadap permasalahan pihak yang bersengketa. Pihak yang menangani konsiliasi disebut konsiliator;

d. Pendapat ahli memberikan argumen sesuai bidang keahliannya untuk melerai sengketa di antara kedua belah pihak.

2. Melalui Arbitrase

Jalur penyelesaian sengketa selain melalui peradilan umum. Arbiter merupakan pihak ketiga yang objektif dan mandiri memiliki kewenangan melakukan pemeriksaan dan mengadili perkara yang diputus oleh pengadilan pada tingkat pertama dan terakhir.

3. Melalui Mekanisme Pengadilan

Mekanisme pengadilan merupakan pertanggungjawaban terhadap penggunaan suatu karya secara komersial tanpa seizin pemilik karya tersebut. Pelanggaran tersebut dapat dikenakan sanksi berupa ganti rugi secara materiel dan nonmateriel.

Perlindungan secara represif pada pelanggaran hak atas merek merujuk pada hasil penelitian Ronna Novy Yosia Taliwongso (2014, h.147-148) yang dapat ditarik kesimpulan bahwa delik hukum di bidang merek, yaitu penggunaan merek tersebut dilakukan dengan sengaja dan tanpa hak memakai merek yang sama pada pokoknya atau keseluruhannya dengan merek terdaftar milik pihak lain atau barang/jasa sejenis yang diproduksi dan/atau diperdagangkan.

Fajar Nurcahya Dwi Putra pada tahun 2014 (h. 102) memberikan contoh bentuk peniruan atas merek terkenal, yaitu merek AQUA yang dimiliki oleh PT Aqua Golden 
Mississipi Tbk bertindak sebagai penggugat dengan merek QUA-QUA yang dimiliki oleh Harry le Khong selaku tergugat. Sesuai putusan Pengadilan Negeri Niaga Jakarta Pusat Nomor 30/Merek/2003/PN.Niaga.Jkt.Pst, secara garis besar isinya berupa Harry le Khong harus menghentikan dan membayar ganti rugi sebanyak Rp. 20.000.000.000,- (dua puluh milyar rupiah) atas produksi dan penggunaan merek yang sama pada pokoknya (merek QUA-QUA) kepada pihak Aqua Golden Mississipi.

Perlindungan secara represif pada rahasia dagang khususnya pada perjanjian kerjasama waralaba, bila ditemukan pelanggaran atas perjanjian kerjasama pihak penerima waralaba mendapat teguran secara tertulis sebanyak 3 (tiga) kali. Jika surat teguran tersebut tidak diperhatikan, maka langkah terakhir adalah pemutusan kontrak kerjasama dari pihak pemberi waralaba (Amirah, Ahmadi Miru, Nurfaidah Said, 2015, h.7-8).

Perlindungan hukum secara represif terhadap sengketa paten dilakukan melalui jalur pengadilan niaga tetapi dapat juga dilakukan secara damai asalkan sesuai dengan peraturan perundang-undangan, yaitu melalui negosiasi, mediasi, konsolidasi, arbitrase, dan jasa baik. (Retna Gumanti, 2015, h. 205). Adapun apabila terjadi pelanggaran terhadap hak paten sebagaimana tercantum dalam Pasal 130 dan Pasal 131 Undang-Undang Nomor 14 Tahun 2001 tentang Paten, bagi pelanggar tersebut dipidana dengan pidana penjara paling lama 4 (empat) tahun atau denda paling banyak Rp.500.000.000,- (lima ratus juta rupiah), dan penjara 2 (dua) tahun atau denda Rp. 250.000.000,- (dua ratus lima puluh juta rupiah)

\section{SIMPULAN}

Hasil kajian literatur menunjukkan bahwa adanya perlindungan hukum dapat dilakukan secara preventif dan represif. Perlindungan preventif dilakukan sebagai upaya hukum untuk mencegah sebelum terjadinya pelanggaran melalui undang-undang dan memberikan manfaat ekonomi bagi pelaku industri kreatif yang mendaftarkan karya intelektualnya. Perlindungan hukum bagi para pencipta dan penemu pada industri kreatif secara umum sudah diberikan melalui perundang-undangan Hak Kekayaan Intelektual. Perlindungan hukum sudah diberikan khususnya bagi produk industri kreatif yang sudah didaftarkan melalui Direktorat Jenderal Kekayaan Intelektual dengan pembuktian berupa kepemilikan sertifikat HKI. Sebaliknya, jika produk industri kreatif tersebut tidak didaftarkan melalui DJKI, maka kekayaan intelektual tersebut tidak dapat diakui dan dilindungi oleh negara. Pendaftaran kekayaan industri atau pencatatan hak cipta sangatlah penting, tanpa adanya pendaftaran maupun pencatatan tidak ada jaminan kepastian hukum tentang hak dan kewajiban pencipta atau penemu atas hasil karya yang telah diciptakan. Selain melalui pendaftaran, bentuk hukum preventif lainnya melalui kontrak/perjanjian. Pelindungan represif dapat dilakukan melalui teguran secara tertulis pada perjanjian kerjasama yang merupakan kesepakatan para pihak. Tindakan represif merupakan upaya pelindungan hukum terakhir berupa sanksi untuk membuat jera pelaku pelanggaran Hak Kekayaan Intelektual tersebut berdasarkan tinjauan hukum pidana dan perdata. 


\section{DAFTAR RUJUKAN}

Amirah, et.al. (2015). Perlindungan Hukum Rahasia Dagang Dalam Perjanjian Kerjasama Waralaba. Jurnal Fakultas Hukum Universitas Hasanuddin, 1(1), 1-12

Anjani, N.L., Susilowati, N. (2015). Perlindungan Karya Seni Fotografi Berdasarkan UndangUndang Nomor 19 Tahun 2002 Tentang Hak Cipta. Jurnal IImu Hukum UNDIP, 1(1), 1-8.

Arma, R.H. (2016). Perlindungan Hukum Hak Cipta dari Kejahatan Pembajakan Software Komputer Menurut Trips Agreement dan Pelaksanaannya di Indonesia. Jurnal Hukum Andalas, 6 (1) Universitas Andalas, 63-89.

Asri, Dyah P.B. (2020). Perlindungan Hukum Hak Kekayaan Intelektual Bagi Produk Kreatif Usaha Kecil Menengah di Yogyakarta. Jurnal Hukum Ius Quia lustum, 27(1), 130-150.

Djumhana, Muhamad. (2010). Perlindungan Hukum Hak Merchandising Dalam Menunjang Pertumbuhan Industri Kreatif di Indonesia Dihubungkan dengan Undang-Undang Nomor 19 Tahun 2002 Tentang Hak Cipta. Jurnal Syiar Hukum, 12(3), 269-284.

Gumanti, Retna. (2015). Perlindungan Hukum terhadap Hak Paten di Indonesia. Jurnal AlMizan, 11( 1), 196-210.

Kusmawan, Denny. (2014). Perlindungan Hak Cipta Atas Buku. Jurnal Perspektif, 19(2), 137143.

Marimis, Rezky Lendi. (2014). Perlindungan Hukum Hak Cipta Atas Karya Musik Dan Lagu Dalam Hubungan dengan Pembayaran Royalti. Jurnal Lex Privatum, 2(2), 116-125.

Pemayun, T.U.N., et.al. (2017). Plagiasi Hak Cipta Karya Seni Rupa di Bali. Wicaksana, Jurnal Lingkungan \& Pembangunan, 1(1), 40-52.

Pratiwi, I.A.W.K. (2014). Pelanggaran Merek Terkenal dan Perlindungan Hukum Bagi Pemegang Hak Dalam Perspektif Paris Convention, Trips Agreement dan UU Merek Indonesia. Jurnal Magister Hukum Udayana, 7(3), 423-438.

Puspitarani, Eva, et.al. (2014). Perlindungan Hukum Terhadap Potret Orang Lain yang Digunakan Promosi oleh Fotografer Berdasarkan Undang-Undang No. 19 Tahun 2002 Tentang Hak Cipta. Jurnal Universitas Jember, 1(1), 1-7.

Putra, Fajar N.D. (2014). Perlindungan Hukum Bagi Pemegang Hak Atas Merek Terhadap Perbuatan Pelanggaran Merek. Jurnal Ilmu Hukum Mimbar Keadilan, 1(3), 97-108.

Rantung, Reyfel A. (2014). Hak Cipta Dalam Jaringan Internet Ditinjau dari Undang-Undang Nomor 19 Tahun 2002 Tentang Hak Cipta. Jurnal IImu Hukum Universitas Sam Ratulangi, 2(1), 101-112.

Rois, M. Fahmi dan Kholis Roisah. (2018). Perlindungan Hukum Kekayaan Intelektual Kerajinan Kuningan Tumang. Kanun Jurnal Ilmu Hukum, 20(3), 401-419.

Rongiyati, S. (2018). Perlindungan Hukum Hak Kekayaan Intelektual Pada Produk Ekonomi Kreatif. Jurnal Negara Hukum, 9 (1), 39-58.

Setyawan, Febri Dwi. (2013). Perlindungan Hak Cipta Atas Program Televisi Dalam UndangUndang Nomor 19 Tahun 2002. Jurnal Agama dan Hak Azasi Manusia, 2(2), 379-406. Sujana, D.S., Susilowati, E. (2015). Arti Penting Perjanjian Tertulis Antara Pemilik Dan 
Pengguna Karya Seni Fotografi Untuk Kepentingan Promosi Komersial. Jurnal Law Reform, 11(1), 43-52.

Taliwongso, Ronna N.Y. (2014). Perlindungan Hukum Atas Hak Kekayaan Intelektual Khususnya Merek di Indonesia. Jurnal Lex et Societatis, 2(8), 147-158.

Yanto, Oksidelfa. (2015). Konsep Perlindungan Hak Cipta Karya Musik Dalam Ranah Hukum Hak Kekayaan Intelektual Dari Tindak Pidana Pembajakan. Jurnal Cita Hukum, 3(1), 99-114.

\section{Undang-Undang}

Republik Indonesia. 2014. Undang-Undang Nomor 28 Tahun 2014 tentang Hak Cipta. Indonesia: Lembaran Negara.

Republik Indonesia. 2000. Undang-Undang Nomor 30 Tahun 2000 tentang Rahasia Dagang. Indonesia: Lembaran Negara.

Republik Indonesia. 2000. Undang-Undang Nomor 14 Tahun 2001 tentang Paten. Indonesia: Lembaran Negara.

Republik Indonesia. 2000. Undang-Undang Nomor 15 Tahun 2001 tentang Merek. Indonesia: Lembaran Negara. 